\title{
Testate amoebae (Amoebozoa: Arcellinidae) as indicators of dissolved oxygen concentration and water depth in lakes of the Lacandón Forest, southern Mexico
}

\author{
Norma Fernanda Charqueño-Celis, ${ }^{1 *}$ Martin Garibay, ${ }^{2}$ Itzel Sigala, ${ }^{2,3}$ Mark Brenner, ${ }^{4}$ Paula Echeverria-Galindo, ${ }^{5}$ \\ Socorro Lozano-García, ${ }^{2}$ Julieta Massaferro, ${ }^{1}$ Liseth Pérez ${ }^{5}$ \\ ${ }^{1}$ CENAC-PNNH-CONICET, Bariloche, Argentina; ${ }^{2}$ Facultad de Ciencias, Universidad Nacional Autónoma de México, Ciudad de \\ México, México; ${ }^{3}$ Instituto de Geología, Universidad Nacional Autónoma de México, Ciudad de México, México; ${ }^{4}$ Department of \\ Geological Sciences and Land Use and Environmental Change Institute (LUECI), University of Florida, Gainesville, FL, USA; \\ ${ }^{5}$ Institut für Geosysteme und Bioindikation, Technische Universität Braunschweig, Germany
}

\begin{abstract}
The ecology of aquatic protists such as testate amoebae is poorly known worldwide, but is almost completely unknown in lakes of the northern Neotropics. To address this knowledge gap, we analyzed testate amoebae (Amoebozoa: Arcellinidae) in lakes of the Lacandón Forest, one of the most biodiverse parts of southern México. We set out to evaluate the diversity of testate amoebae communities and assess whether testate amoebae taxa are reliable indicators of environmental variables dissolved oxygen and water depth. We collected 17 surface sediment samples from a range of water depths in six lakes across the Naha-Metzabok Biosphere Reserve, northeastern Chiapas state. We identified 15 testate amoebae taxa distributed across seven genera. Eleven were identified to species level and four to strain (infra-subspecific level), and taxa were distributed unevenly among samples. Distribution of taxa in samples was related to dissolved oxygen (DO) concentration in the water measured near the sediment surface. Arcella discoides and Centropyxis aculeata strain "aculeata" were the most tolerant of low oxygen concentrations, whereas the other taxa require higher DO levels. The influence of oxygen was also seen at the assemblage level. Sites with low DO concentrations had Shannon Diversity Index (SDI) values $<1.5$, an indication of stressful ambient conditions. We identified two species assemblage types, which are distinguished by their oxygen concentration requirements. Assemblage 1 was more diverse and possessed species that are intolerant of low oxygen concentrations, whereas Assemblage 2 possessed fewer, rarer, opportunistic species that tolerate stressful conditions. Low oxygen concentrations are related to water depth and the combination of these two variables is important in determining the composition of testate amoebae assemblages in Lacandón Forest lakes. Quantitative relationships between testate amoebae assemblages and water depth will enable use of sedimented amoebae remains for paleolimnological inference of past water level changes in lakes of the Lacandón Forest.
\end{abstract}

\section{INTRODUCTION}

Aquatic protists in biodiverse ecosystems of the Neotropics have received little attention. For example, little

Corresponding author: fcharquenocelis@comahue-conicet.gob.ar

Key words: Testate amoebae; neotropics; bioindicators; dissolved oxygen; water depth; Lacandón Forest.

Authors' contributions: All the authors made a substantive intellectual contribution, performed part of the experiments. All the authors have read and approved the final version of the manuscript and agreed to be accountable for all aspects of the work.

Edited by: Ester Eckert, CNR-IRSA Verbania, Italy

Received: 16 August 2019.

Accepted: 11 December 2019.

This work is licensed under a Creative Commons Attribution NonCommercial 4.0 License (CC BY-NC 4.0).

${ }^{\circ}$ Copyright: the Author(s), 2019

Licensee PAGEPress, Italy

J. Limnol., 2020; 79(1): 82-91

DOI: 10.4081/jlimnol.2019.1936 is known of these organisms in lakes of the Lacandón Forest $\left(16^{\circ} 45^{\prime} 0^{\prime \prime} \mathrm{N}, 91^{\circ} 30^{\prime} 0^{\prime \prime} \mathrm{W}\right)$ in northeastern Chiapas state, México. This forest is a biodiversity hotspot that hosts a vast amount of Mexican biodiversity with respect to vertebrates $(46 \%)$, butterflies $(60 \%)$ and plants $(50 \%)$ (Castillo-Campos and Narave, 1992; Lazcano-Barrero et al., 1992; Conanp, 2006b). In 2010 UNESCO declared two of its five natural protected areas (NPAs), Metzabok and Naha, a Biosphere Reserve. Although there are numerous lacustrine systems in the area, knowledge of the aquatic biota in the region is limited to fish, amphibian and reptile inventories (Conanp, 2006a). More recently, Díaz et al. (2017) and Vázquez-Molina et al. (2016) published paleolimnological studies that employed sedimented ostracods and cladocerans, respectively. Whereas the primary goal of those studies was paleoenvironmental inference, they contributed to knowledge about the biota of these lakes and highlighted the importance of modern ecological studies in this poorly studied area of México.

One goal of neoecological studies is to understand the relation between communities and environmental variables and assess the sensitivity of taxa to climate and environmental changes (Mcgill et al., 2006). Communities and subfossil assemblages are useful bioindicators of modern and past conditions, respectively (Smol et al., 2001). Testate amoebae are abundant 
components of benthic communities and are highly sensitive to environmental conditions (Yeates and Foissner, 1995; Neville et al., 2010; Han et al., 2011). They are a polyphyletic group of free-living protists, whose main character is a test ("shell") that protects the cytoplasm. They possess a simple aperture for extrusion of pseudopods (Medioli and Scott, 1988; Beyens and Meisterfeld, 2006). Testate amoebae are present in all kinds of lakes, from the littoral to the profundal zone (Sigala et al., 2016). A number of studies have shown strong relationships between lacustrine testate amoebae community composition and variables such as salinity, conductivity, $\mathrm{pH}$ and human impacts (Patterson et al., 1996; Roe et al., 2010; Patterson et al., 2012), suggesting that these protists are useful modern and paleoenvironmental bioindicators.

A few studies in the Neotropics identified the effect of dissolved oxygen on the structure of testate amoebae communities (Dalby et al., 2000; Roe et al., 2010; Sigala et al., 2018). Our goal was to evaluate the role of dissolved oxygen concentration in determining the structure and diversity of testate amoebae communities in lakes of the Lacandón Forest, Chiapas, México. We hypothesized that testate amoeba diversity would be directly correlated with oxygen concentration, which in turn, might be inversely related to lake water depth. We sought to gather fundamental data about the ecology of these tropical protists, and to explore their potential for use as bioindicators.

\section{METHODS}

This study was carried out in the Naha-Metzabok Biosphere Reserve, in the Lacandón Forest of northeastern Chiapas State (16 $\left.{ }^{\circ} 95^{\prime} 0^{\prime \prime} \mathrm{N}, 90^{\circ} 78^{\prime} 0^{\prime \prime} \mathrm{W}\right)$. Mean annual temperature in the area is $23.6^{\circ} \mathrm{C}$ and the mean annual precipitation is $\sim 1860 \mathrm{~mm}$. Regional vegetation is a mosaic of tropical rain forest, cloud forest, and coniferous forest elements, mixed with large patches of agriculture and pasture (Rzedowski, 2006). The area is a karstic platform of Cretaceous marine origin (Padilla, 2007) and is characterized by calcareous hills and valleys with altitudes that range from 580 to $1800 \mathrm{~m}$ asl. Two major rivers in the region, the Lacanjá and Lacantún, feed 21 lakes that differ with respect to their geomorphological characteristics (Conabio, 2013a, 2013b). An important hydrological feature of this karst region is the groundwater, which influences lake water levels and governs hydrologic connectivity between the lakes.

We collected 17 surface sediment samples from different water depths in six lakes across the Lacandón Forest (Fig. 1), Chiapas México, in March 2015 and June 2016. Samples were collected with an Ekman grab (Tab. 1). Water temperature, dissolved oxygen, $\mathrm{pH}$ and conductivity were measured in situ near the sediment surface using a YSI EX01 Multi-parameter probe (Yellow Springs, OH, USA). Sediment samples were preserved in absolute ethanol and subsamples of $1 \mathrm{~cm}^{3}$ wet volume were

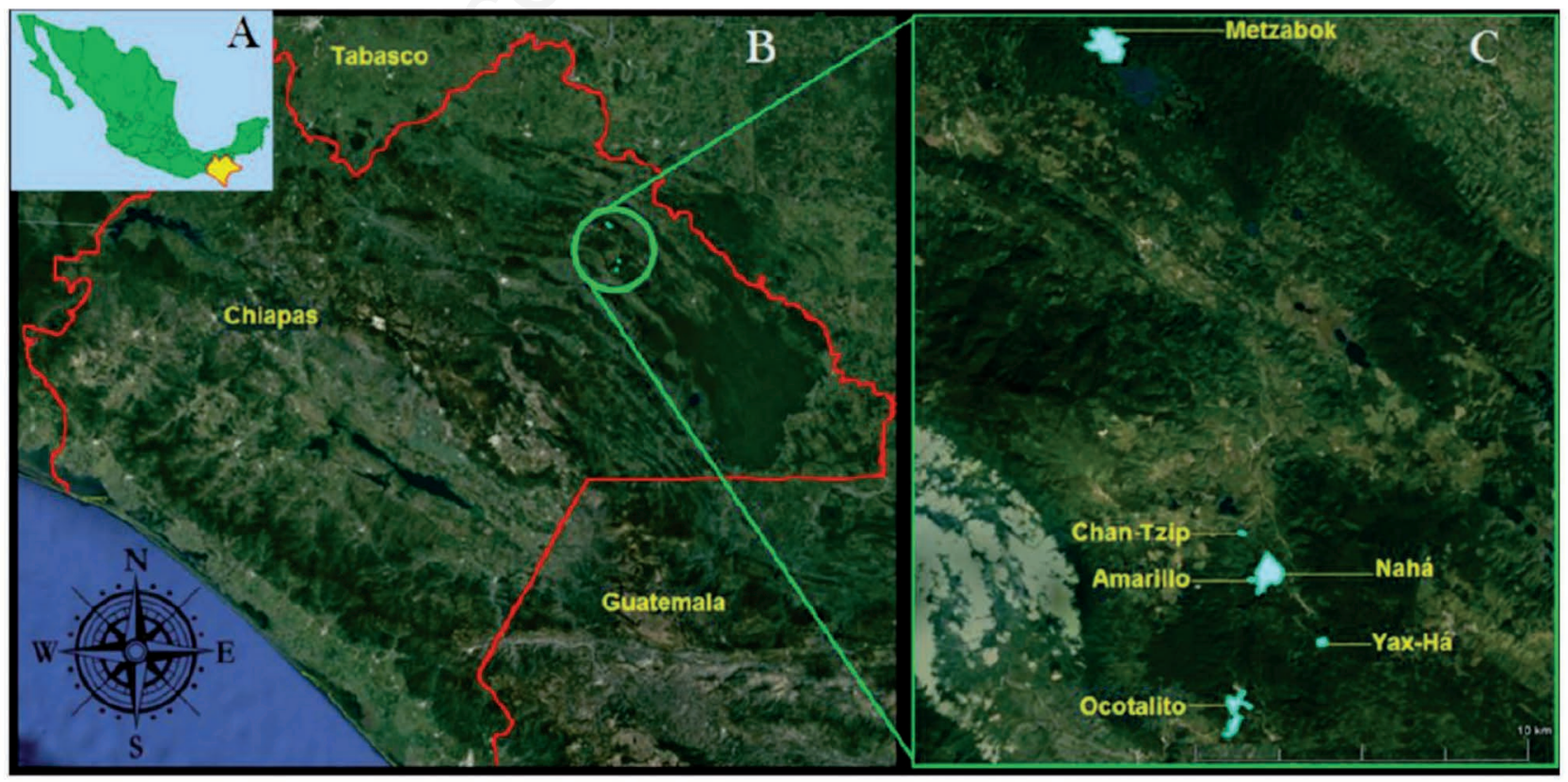

Fig. 1. Map showing the locations of the six lakes sampled in the Lacandón Forest, Chiapas, Mexico. Inset map (A) shows the location of the state of Chiapas in southern Mexico. 
removed for analysis. In the lab, each subsample was examined under a ZEISS Stemi 508 stereomicroscope and testate amoebae were extracted using a fine brush (Ellison and Ogden, 1987). Pre-identification was done with an optical microscope, using the descriptions of Sigala et al. (2016) and confirmed with photographs taken using a ZEISS EVO MA10 scanning electron microscope (SEM) and comparison with the taxonomic keys of Ogden and Hedley (1980), Kumar and Dalby (1998) and Lee et al. (2000). Lacustrine arcellacean species can display broad eco-phenotypically controlled morphological variability. Therefore, it is common to assign informal, infrasubspecific 'strain' names to eco-phenotypes to avoid inadvertent unwarranted description of new species. Although the International Code of Zoological Nomenclature stipulates that infra-subspecfic-level designations have no status (ICZN, 1999), in testate amoebae studies they are useful for distinguishing environmentally distinct populations in lacustrine environments (Patterson et al., 2012).

\section{Statistical analyses}

Statistical analyses were carried out in the $\mathrm{R}$ environment version 3.5.3 ( $\mathrm{R}$ Core Team, 2019), specifically with the Vegan package (Oksanen et al., 2019). To visualize testate amoebae distributions along the dissolved oxygen gradient, we constructed an
INKSPOT-plot. That is a two-way, ordered "bubble" plot of testate amoebae by sites, with sites arrayed along the $\mathrm{x}$-axis, species on the $\mathrm{y}$-axis, and abundance indicated by the symbol ("bubble") size.

Testate amoebae assemblage diversity is described using the Shannon Diversity Index (SDI). The SDI is defined in the equation below, with $\mathrm{Xi}=$ abundance of individuals of a species (i) in the sample; $\mathrm{Ni}=$ total number of individuals in the sample; $\mathrm{S}=$ species richness (i.e. number of species) in the sample:

$$
S D I=\sum_{I=1}^{S}\left(\frac{X_{i}}{N_{i}}\right) \times \ln \left(\frac{X_{i}}{N_{i}}\right)
$$

According to Patterson and Kumar (2002), the index value is an indication of the stress condition at the site where testate amoebae were collected. An SDI value between 2.5 and 3.5 indicates "stress-free" conditions for testate amoebae. If the site does not possess optimal conditions for the organisms, values of the index are between 1.5 and 2.5. In contrast, sites with poor environmental conditions for testate amoebae have low SDI values, between 0.1 and 1.5 .

To test if the number of species present in each sample was statistically significant for analysis, we calculated the standard error (Sxi) associated with each taxon using the following formula:

Tab. 1. Environmental variables for sampled study lakes in the Lacandón Forest, Chiapas, Mexico. Reported values reflect those measured in the water column, just above the sediment surface.

\begin{tabular}{|c|c|c|c|c|c|c|c|c|c|c|}
\hline Lake name & Code & $\begin{array}{l}\text { Latitude } \\
\text { (N) }\end{array}$ & $\begin{array}{l}\text { Longitude } \\
\text { (W) }\end{array}$ & Year & $\begin{array}{l}\text { Depth } \\
\text { (m) }\end{array}$ & $\begin{array}{l}\text { Altitude } \\
\text { (m asl) }\end{array}$ & $\begin{array}{c}\text { Dissolved } \\
\text { oxygen } \\
\left(\mathrm{mg} \mathrm{L}^{-1}\right)\end{array}$ & $\mathrm{pH}$ & $\begin{array}{c}\text { Temperature } \\
\left({ }^{\circ} \mathrm{C}\right)\end{array}$ & $\begin{array}{c}\text { Electrical } \\
\text { conductivity } \\
\left(\mu \mathrm{S} \mathrm{cm}^{-1}\right)\end{array}$ \\
\hline Metzabok & M510 & $17^{\circ} 07^{\prime} 54.18^{\prime \prime}$ & $91^{\circ} 38^{\prime} 37.65^{\prime \prime}$ & 2015 & 10.57 & 550 & 4.21 & 7.75 & 21.60 & 390 \\
\hline Metzabok & M607 & $17^{\circ} 07^{\prime} 53.89^{\prime \prime}$ & $91^{\circ} 38^{\prime} 23.93^{\prime \prime}$ & 2016 & 6.50 & 550 & 6.94 & 8.12 & 29.10 & 289 \\
\hline Metzabok & M610 & $17^{\circ} 07^{\prime} 45.15^{\prime \prime}$ & $91^{\circ} 38^{\prime} 08.27^{\prime \prime}$ & 2016 & 9.90 & 550 & 6.28 & 7.80 & 27.70 & 287 \\
\hline Metzabok & M613 & $17^{\circ} 07^{\prime} 52.27^{\prime \prime}$ & $91^{\circ} 38^{\prime} 03.56^{\prime \prime}$ & 2016 & 13 & 550 & 4.83 & 7.63 & 26.80 & 294 \\
\hline Nahá & N517 & $16^{\circ} 59^{\prime} 24.10^{\prime \prime}$ & $91^{\circ} 35^{\prime} 56.70^{\prime \prime}$ & 2015 & 17.66 & 832 & 4.90 & 7.69 & 20.60 & 495 \\
\hline Nahá & N522 & $16^{\circ} 59^{\prime} 39.43^{\prime \prime}$ & $91^{\circ} 35^{\prime} 23.51^{\prime \prime}$ & 2015 & 22.09 & 832 & 1.29 & 7.49 & 20.60 & 496 \\
\hline Nahá & N624 & $16^{\circ} 59^{\prime} 08.68^{\prime \prime}$ & $91^{\circ} 35^{\prime} 38.45^{\prime \prime}$ & 2016 & 23.50 & 832 & 0.52 & 7.47 & 20.60 & 348 \\
\hline Amarillo & A510 & $16^{\circ} 58^{\prime} 56.45^{\prime \prime}$ & $91^{\circ} 30^{\prime} 31.52^{\prime \prime}$ & 2015 & 10.35 & 867 & 0.32 & 7.40 & 20.70 & 346 \\
\hline Amarillo & A610 & $16^{\circ} 58^{\prime} 57.17^{\prime \prime}$ & $91^{\circ} 30^{\prime} 31.74^{\prime \prime}$ & 2016 & 9.37 & 867 & 0.92 & 7.10 & 21.10 & 283 \\
\hline Yaxhá & Y529 & $16^{\circ} 57^{\prime} 53.48^{\prime \prime}$ & $91^{\circ} 35^{\prime} 42.70^{\prime \prime}$ & 2015 & 28.74 & 930 & 1.05 & 7.36 & 21.30 & 296 \\
\hline Yaxhá & Y 625 & $16^{\circ} 57^{\prime} 57.98^{\prime \prime}$ & $91^{\circ} 35^{\prime} 55.58^{\prime \prime}$ & 2016 & 25.04 & 930 & 3.50 & 7.58 & 21.40 & 200 \\
\hline Yaxhá & Y630 & $16^{\circ} 57^{\prime} 57.08^{\prime \prime}$ & $91^{\circ} 35^{\prime} 23.87^{\prime \prime}$ & 2016 & 30 & 930 & 0.21 & 7.36 & 21.40 & 227 \\
\hline Ocotalito & O508 & $16^{\circ} 56^{\prime} 34.27^{\prime \prime}$ & $91^{\circ} 36^{\prime} 04.76^{\prime \prime}$ & 2015 & 7.57 & 946 & 5.63 & 7.93 & 21.30 & 313 \\
\hline Ocotalito & O521 & $16^{\circ} 56^{\prime} 40.21^{\prime \prime}$ & $91^{\circ} 36^{\prime} 48.54^{\prime \prime}$ & 2015 & 21.01 & 946 & 0.11 & 7.28 & 20.20 & 341 \\
\hline Ocotalito & O605 & $16^{\circ} 57^{\prime} 36.07^{\prime \prime}$ & $90^{\circ} 56^{\prime} 44.34^{\prime \prime}$ & 2016 & 5.02 & 946 & 5.16 & 8.22 & 26.90 & 234 \\
\hline Ocotalito & O619 & $16^{\circ} 59^{\prime} 05.08^{\prime \prime}$ & $91^{\circ} 35^{\prime} 31.32^{\prime \prime}$ & 2016 & 19.10 & 946 & 0.22 & 7.44 & 20.10 & 231 \\
\hline Chan-Tzip & $\mathrm{C} 508$ & $16^{\circ} 58^{\prime} 47.73^{\prime \prime}$ & $91^{\circ} 37^{\prime} 56.75^{\prime \prime}$ & 2015 & 7.50 & 950 & 1.15 & 7.96 & 20.60 & 425 \\
\hline
\end{tabular}




$$
S_{X I}=1.96 \sqrt{\frac{F_{i}\left(1-F_{i}\right)}{N_{i}}}
$$

where Fi is the relative fractional abundance of each taxon and $\mathrm{Ni}$ is the total number of individuals of all species in each sample. If the Sxi value is greater than the relative fractional abundance, then it is not statistically significant and cannot be included in the multivariate analysis (Patterson and Fishbein, 1989; Patterson et al., 2012). In this study, all species abundances were statistically significant and included in the analysis. We then organized species and sample data into a hierarchical diagram using Q-mode and R-mode cluster analysis and Wards minimum variance method, using Ward distance (Patterson and Kumar, 2002; Roe and Patterson, 2014). Lastly, we applied a permutational multivariate analysis of variance (PERMANOVA) with two variables (dissolved oxygen and water depth) to assess the statistical significance of the effects of the environmental variables on testate amoebae assemblages, accomplished with the hierarchical diagram and non-metric multi-dimensional scaling (NMDS) (Anderson, 2017). This was used to describe patterns in testate amoebae assemblages and assess relationships among testate amoebae communities and dissolved oxygen and water depth. NMDS is a robust non-parametric ordination method for analyzing ecological community data, which does not make assumptions regarding the underlying species distribution patterns.

\section{RESULTS}

Testate amoebae were present at all sites sampled. A total of 15 taxa distributed across seven genera were identified. Eleven were identified to species level and four were assigned to an infra-subspecific level, hereafter referred to as "strain" (Tab. 2). Abundance of taxa was plotted against dissolved oxygen concentration values (Fig. 2) and shows that the diversity of testate amoebae changes in accordance with oxygen concentrations. Centropyxis aculeata strain "aculeata" and Arcella discoides were the most common and abundant taxa in the samples. Remaining taxa displayed preferences for higher concentrations of dissolved oxygen (Fig. 2). Sites with the highest oxygen concentrations $\left(>4 \mathrm{mg} \mathrm{L}^{-1}\right)$ yielded SDI values $>1.5$, whereas samples from sites with relatively low oxygen concentrations $\left(<4 \mathrm{mg} \mathrm{L}^{-1}\right)$ had SDI values between 0 and 1.5 (Fig. 3).

Statistical analysis revealed the effect of dissolved oxygen concentration on testate amoebae diversity. The Q-mode and R-mode cluster analysis and NMDS, based on the abundance and distribution of testate amoebae, enabled identification of two main assemblage types (Fig. 4 ), which are related to the tolerance of taxa to oxygen concentrations, and the water depth at the sampling site (Fig. 5). PERMANOVA results showed there is a stronger correlation between testate amoebae distribution and dissolved oxygen $(\mathrm{F}=3.4, \operatorname{Pr}(>\mathrm{F})=0.01)$ than between the protists and water depth $(\mathrm{F}=0.68, \operatorname{Pr}(>\mathrm{F})=0.64)$. Nevertheless, the interaction between the two variables also had a significant effect on the rhizopod assemblages $(F=3.01, \operatorname{Pr}(>F)=0.03)($ Tab. 3, Fig. 3).

\section{Assemblage 1}

This group was dominant primarily in samples from Lakes Metzabok, Yaxhá and Naha, and generally had high abundances of $C$. constricta strain "aerophila" (Fig. 3), as well as relatively high SDI values (>1.4) (Fig. 3). This assemblage is associated with the positive ordination NMDS axis 1 (Fig. 5), with high abundances of D. oblonga strain "oblonga", D. bidens and M. corona. Difflugia protaeiformis strain "acuminata", $L$. spiralis, $D$. protaeiformis strain "amphoralis", L. vas, and C. constricta strain "spinosa" were encountered only at these sites. Assemblage 1 was also related to high values of dissolved oxygen, as well as to intermediate water depths (Fig. 5).

\section{Assemblage 2}

In general, sites characterized by Assemblage 2 had low SDI value $(<1.5)$ (Fig. 3) because of the strong dominance of $C$. aculeata strain "aculeata" and $A$. discoides. The rest of the species were absent or present at low abundances (Fig. 4). Assemblage 2 samples came

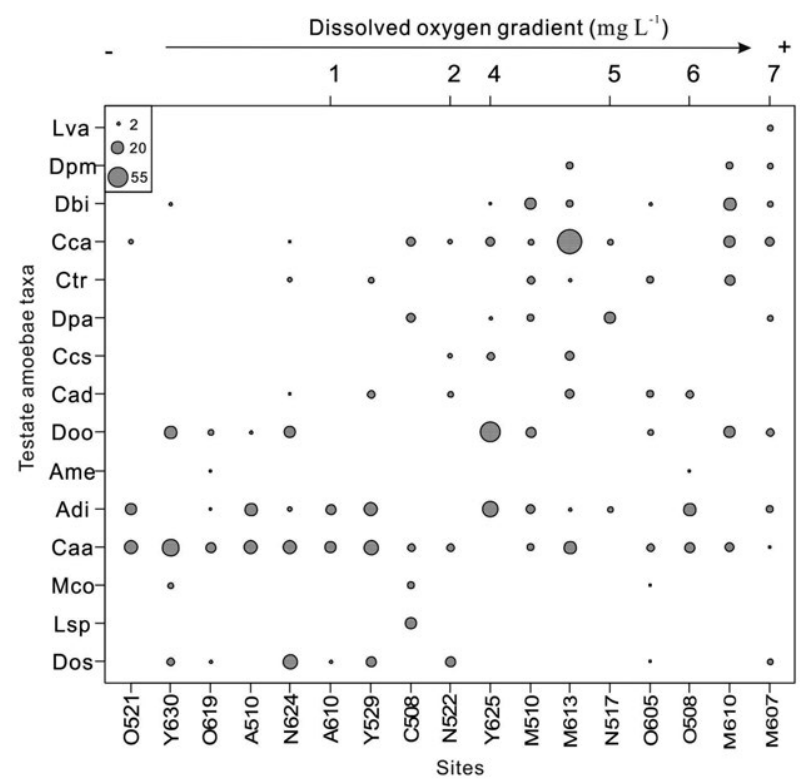

Fig. 2. INKSPOT plot of the abundance of testate amoebae along a dissolved oxygen gradient. The code for sample sites is in Tab. 1 and the codes for testate amoebae species are in Tab. 2. 
from Lakes Amarillo, Ocotalito, Yaxhá and Naha. This assemblage is related to the negative side of NMDS axis 1 (Fig. 5) and also contains species such as A.discoides, $D$. oblonga strain "spinosa", C. aculeata strain "discoides" and A. megastoma. In contrast to Assemblage
1, Assemblage 2 is associated with low values of dissolved oxygen, (Fig. 5), and is found in samples from relatively deep water, dominated by $C$. aculeata strain "aculeata" and $A$. discoides. The rest of the species were absent or present at low abundances (Fig. 5).

Tab. 2. Relative abundances of testate amoebae in lakes of the Lacandón Forest. See Tab. 1 for ID codes associated with each lake. AMOEBOZOA Lühe,

1913

*Tubulinea Smirnov

et al., 2005

**Arcellinida Kent,

1880

***Arcellina Haeckel,

1894

\begin{tabular}{lllllllllllllllllll}
\hline Arcella discoides & ADI & 0.00 & 0.29 & 0.31 & 0.00 & 0.45 & 0.42 & 0.15 & 0.00 & 0.04 & 0.14 & 0.12 & 0.00 & 0.01 & 0.49 & 0.38 & 0.00 & 0.04
\end{tabular}

Ehrenberg, 1843

\begin{tabular}{lllllllllllllllllll}
\hline Arcella megastoma & AME & 0.00 & 0.00 & 0.00 & 0.00 & 0.00 & 0.00 & 0.00 & 0.00 & 0.00 & 0.00 & 0.00 & 0.00 & 0.00 & 0.02 & 0.00 & 0.00 & 0.04
\end{tabular} Penard, 1902

****ifflugina

Meisterfeld, 2002

\begin{tabular}{lllllllllllllllllll}
\hline Centropyxis aculeata & CAA & 0.16 & 0.37 & 0.00 & 0.53 & 0.51 & 0.52 & 0.00 & 0.24 & 0.31 & 0.09 & 0.02 & 0.12 & 0.14 & 0.29 & 0.55 & 0.29 & 0.65
\end{tabular}

Ehrenberg, 1832 strain

"aculeata"

\begin{tabular}{lllllllllllllllllll}
\hline Centropyxis aculeata & CAD & 0.00 & 0.12 & 0.00 & 0.00 & 0.00 & 0.00 & 0.00 & 0.15 & 0.01 & 0.00 & 0.00 & 0.00 & 0.08 & 0.20 & 0.00 & 0.23 & 0.00
\end{tabular}

Ehrenberg, 1832 strain

"discoides"

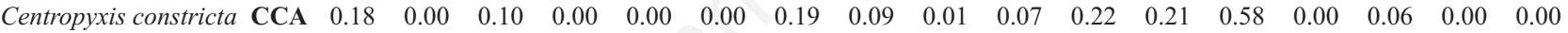
Ehrenberg, 1843 strain

"aerophila"

\begin{tabular}{lllllllllllllllllll}
\hline Centropyxis constricta & CCS & 0.00 & 0.00 & 0.07 & 0.00 & 0.00 & 0.00 & 0.00 & 0.09 & 0.00 & 0.00 & 0.00 & 0.00 & 0.07 & 0.00 & 0.00 & 0.00 & 0.00
\end{tabular}

Ehrenberg, 1843 strain

"spinosa"

\begin{tabular}{lllllllllllllllllll}
\hline Cucurbitella tricuspis & CTR & 0.00 & 0.05 & 0.00 & 0.00 & 0.00 & 0.00 & 0.00 & 0.00 & 0.04 & 0.13 & 0.00 & 0.15 & 0.01 & 0.00 & 0.00 & 0.19 & 0.00
\end{tabular}

(Carter, 1856)

$\begin{array}{lllllllllllllllllll}\text { Difflugia bidens } & \text { DBI } & 0.00 & 0.00 & 0.01 & 0.03 & 0.00 & 0.00 & 0.00 & 0.00 & 0.00 & 0.25 & 0.10 & 0.25 & 0.04 & 0.00 & 0.00 & 0.06 & 0.00\end{array}$

Penard, 1902

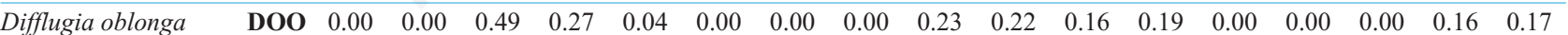

Ehrenberg, 1832

strain "oblonga"

\begin{tabular}{|c|c|c|c|c|c|c|c|c|c|c|c|c|c|c|c|c|c|c|}
\hline $\begin{array}{l}\text { Difflugia oblonga } \\
\text { Ehrenberg, } 1832 \\
\text { strain "spinosa" }\end{array}$ & DOS & 0.00 & 0.17 & 0.00 & 0.12 & 0.00 & 0.06 & 0.00 & 0.44 & 0.36 & 0.00 & 0.08 & 0.00 & 0.00 & 0.00 & 0.00 & 0.03 & 0.09 \\
\hline $\begin{array}{l}\text { Difflugia protaeiformis } \\
\text { Lamarck, } 1816 \\
\text { strain "acuminata" }\end{array}$ & DPA & 0.21 & 0.00 & 0.02 & 0.00 & 0.00 & 0.00 & 0.67 & 0.00 & 0.00 & 0.10 & 0.10 & 0.00 & 0.00 & 0.00 & 0.00 & 0.00 & 0.00 \\
\hline $\begin{array}{l}\text { Difflugia protaeiformis } \\
\text { Lamarck, } 1816 \\
\text { strain "amphoralis" }\end{array}$ & DPM & 0.00 & 0.00 & 0.00 & 0.00 & 0.00 & 0.00 & 0.00 & 0.00 & 0.00 & 0.00 & 0.10 & 0.08 & 0.04 & 0.00 & 0.00 & 0.00 & 0.00 \\
\hline $\begin{array}{l}\text { Lagenodifflugia vas } \\
\text { Leidy, } 1874\end{array}$ & LVA & 0.00 & 0.00 & 0.00 & 0.00 & 0.00 & 0.00 & 0.00 & 0.00 & 0.00 & 0.00 & 0.10 & 0.00 & 0.00 & 0.00 & 0.00 & 0.00 & 0.00 \\
\hline $\begin{array}{l}\text { Lesquereusia spiralis } \\
\text { Ehrenberg, } 1840\end{array}$ & LSP & 0.32 & 0.00 & 0.00 & 0.00 & 0.00 & 0.00 & 0.00 & 0.00 & 0.00 & 0.00 & 0.00 & 0.00 & 0.00 & 0.00 & 0.00 & 0.00 & 0.00 \\
\hline $\begin{array}{l}\text { Mediolus corona } \\
\text { Vallich } 1864\end{array}$ & MCO & 0.13 & 0.00 & 0.00 & 0.05 & 0.00 & 0.00 & 0.00 & 0.00 & 0.00 & 0.00 & 0.00 & 0.00 & 0.00 & 0.00 & 0.00 & 0.03 & 0.00 \\
\hline
\end{tabular}

Wallich 1864 


\section{DISCUSSION}

Abundances and distributions of testate amoebae taxa in Lacandón Forest lakes are related strongly to dissolved oxygen concentration in the bottom waters (Fig. 6). These protists are well represented in lakes of the Lacandón Forest, however distribution of taxa among the water bodies is heterogenous (Fig. 2). This is reflected in the Shannon Diversity Index values from these sites, which indicate low alpha diversity in sites with low dissolved oxygen. Strong dominance of a few tolerant species in sites with low oxygen concentrations results in low SDI values (Fig. 3). According to Patterson and Kumar (2002), SDI values $<1.5$ reflect a stressful environment for testate amoebae. We concluded that low oxygen concentrations in these Neotropical lakes constitute unfavorable environmental conditions for these protists.

Species less tolerant of low oxygen concentration were clustered in Assemblage 1, whereas species more tolerant of low dissolved oxygen were present in Assemblage 2. In the first assemblage, Centropyxis constricta strain "aerophila" was the most common and abundant taxon, however it displayed low representation in samples of Assemblage 2 (Fig. 4). Centropyxis constricta strain "aerophila" has been reported in both central México and the Yucatan Peninsula (Van Hengstum et al., 2008; Sigala et al., 2016). Those studies related the distribution of C. constricta "aerophila" to salinity and conductivity and the authors considered this taxon to be euryhaline. In our study, distribution of this taxon appears to have been determined by the amount of dissolved oxygen in the water, as we saw little difference in conductivity values across sampling sites (Tab. 1).

$C$. aculeata strain "aculeata" and A. discoides displayed high relative abundance, mainly in Assemblage 2 samples (Fig. 3). Both testate amoebae are typical opportunistic species, recorded in hostile conditions in tropical, subtropical and temperate environments with very low $\mathrm{pH}$ and high salinity, and even in badly polluted waters (Dalby et al., 2000; Patterson and Kumar, 2000; Escobar et al., 2005; Sigala et al., 2018). Our results confirm this interpretation, as these two taxa were found in sites with low dissolved oxygen concentrations (Fig. 2).

As many variables may influence the distribution of testate amoebae taxa, it can be difficult or impossible to isolate the effect of a single variable such as dissolved oxygen from other variables in complex aquatic ecosystems (Legendre and Anderson, 1999). Our PERMANOVA results indicate that even though testate amoebae distribution is related to oxygen concentration, the organisms may in fact be responding to the interacting effects of oxygen concentration and water depth (Tab. 3). Dalby et al. (2000) identified a strong relationship between dissolved oxygen concentration and these protists in a thermally stratified lake in Indonesia. Lake

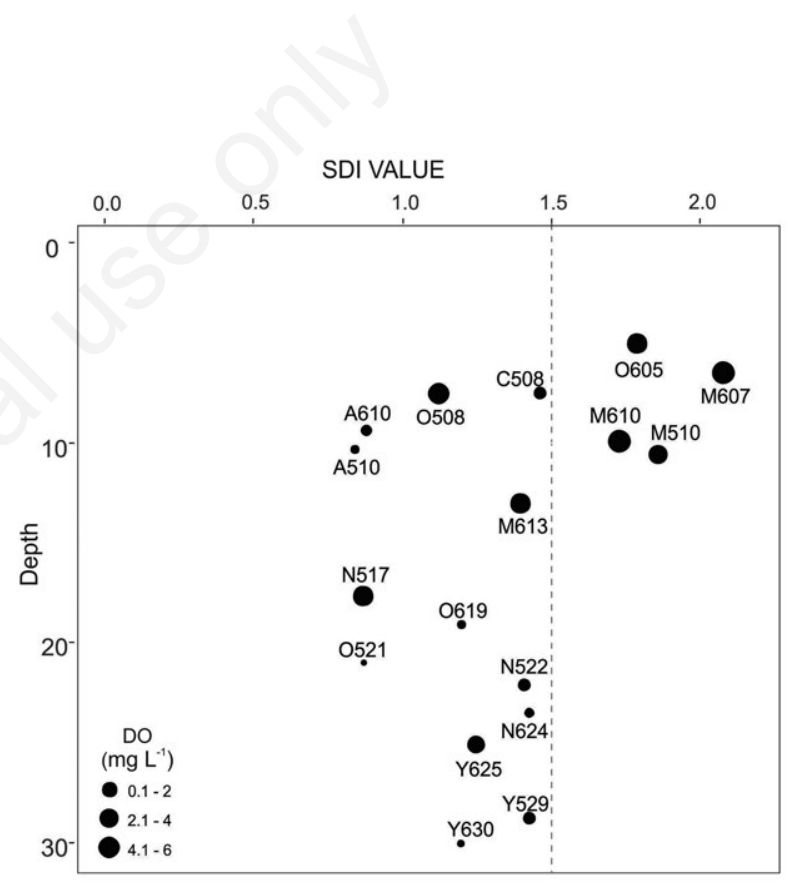

Fig. 3. Relationship between Shannon Diversity Index (SDI) value and water depth of each sample. The bubbles in the code lakes represent the dissolved oxygen concentration at each sample site. The red dashed line represents the limit between stressful conditions ( $\mathrm{SDI}=0.1-1.5)$ and transition conditions (SDI $=1.5$ 2.5) according to Patterson and Kumar (2002). Codes for each lake are given in Tab. 1.

Tab. 3. Results of PERMANOVA analysis to assess the effects of single and interacting factors (dissolved oxygen and water depth) on testate amoebae distribution in Lacandón Forest lakes.

\begin{tabular}{lcccccc} 
& Df & SS & $\mathrm{R}^{2}$ & & & Pr $(>\mathrm{F})$ \\
Dissolved oxygen & 1 & 0.52 & 0.17 & 3.44 & $\mathbf{0 . 0 1}$ & 0.64 \\
\hline Water depth & 1 & 0.10 & 0.04 & 0.68 & $\mathbf{0 . 0 3}$ & \\
\hline Dissolved oxygen + water depth & 1 & 0.46 & 0.15 & 3.01 & & \\
\hline Residual & 13 & 1.97 & 0.65 & & &
\end{tabular}


stratification results in persistent isolation of bottom waters and progressive reduction of oxygen in the hypolimnion. This, in turn, can have a negative impact on the survival of benthic organisms, as indicated by the stressed arcellacean fauna in this study. Limnological investigations in several lakes close to the Lacandón Forest showed that most stratify and develop hypolimnetic anoxia (Alcocer et al., 2016). Although we did not do a detailed characterization of limnological conditions in our study lakes, we did observe a decrease in dissolved oxygen concentration with increasing water depth in the lakes (Fig. 3). We note, however, that other factors, not measured in this study, may influence the concentration of dissolved oxygen and thereby affect the testate amoebae community. Roe et al. (2010) reported low oxygen associated with polluted sites in temperate lakes. With respect to our lakes, it is unlikely that pollutants play a role in influencing arcellacean distributions, as the water bodies are far from industrial pollutant sources and mines. Low oxygen concentrations in some of the lakes, however, may be related to lake productivity, which in turn, is related to the anthropogenic history of the area, i.e. land use changes around the lakes (Trench, 2005).

Our preliminary study suggests that further efforts should be directed at identifying the relation between dissolved oxygen concentrations and testate amoebae assemblages. In particular, it would be worthwhile to determine the optima and ranges of oxygen concentration for individual taxa. Additionally, a more rigorous study of testate amoebae distributions along a water depth gradient could better define the influence of this variable on distributions of taxa. In this study, we deliberately did not sample the littoral zone of the lakes to avoid the potential effect of macrophytes, which have been reported as important determinants of testate amoebae presence in some studies (Alves et al., 2010; Neville et al., 2010). Future analysis of littoral zone samples from Lacandón Forest lakes will almost certainly result in an increase in the number of taxa recorded and better knowledge of the ecology of testate amoebae in these tropical lakes. Acquisition of additional ecological information about testate amoebae in tropical regions will enable the use of these protists as bioindicators of modern water quality conditions, and as variables in paleolimnological studies for inference of past changes in water level, lacustrine productivity, oxygen concentration, conductivity and $\mathrm{pH}$.

\section{CONCLUSIONS}

This study was the first to explore testate amoebae in lakes of the Lacandón Forest, Chiapas state, southern Mexico. Testate amoebae in Lacandón water bodies display different tolerances to low dissolved oxygen concentrations in the water column. Some species are less tolerant of low DO concentrations, such as $C$. constricta strain "aerophila", whereas C. aculeata strain "aculeata"

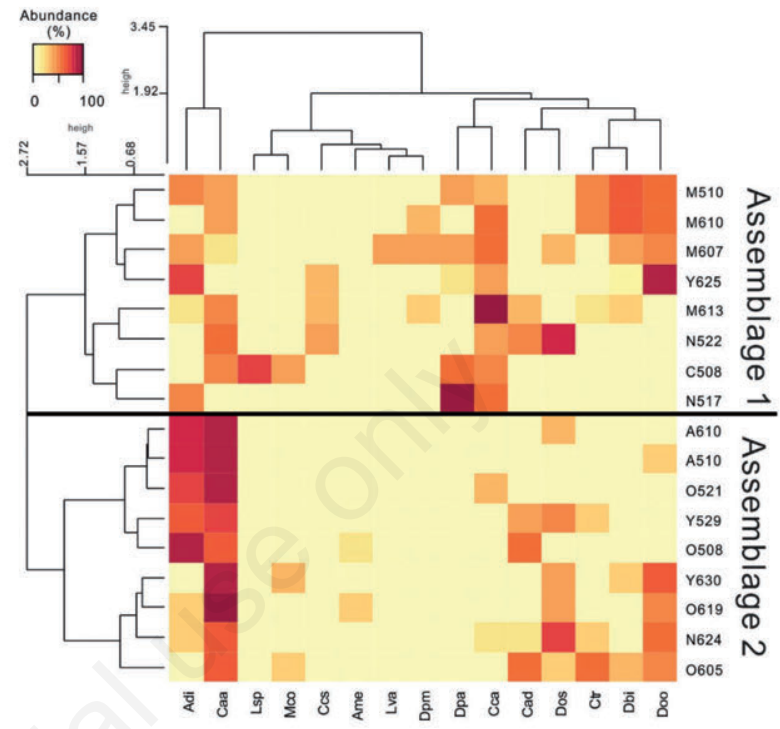

Fig. 4. Abundance of testate amoebae represented as a Q-mode and $\mathrm{R}$ mode cluster analyses. We included only statistically significant species and samples. According to the graph we differentiated two principal assemblages. Codes for samples are in Tab. 1 and codes for species are in Tab. 2.

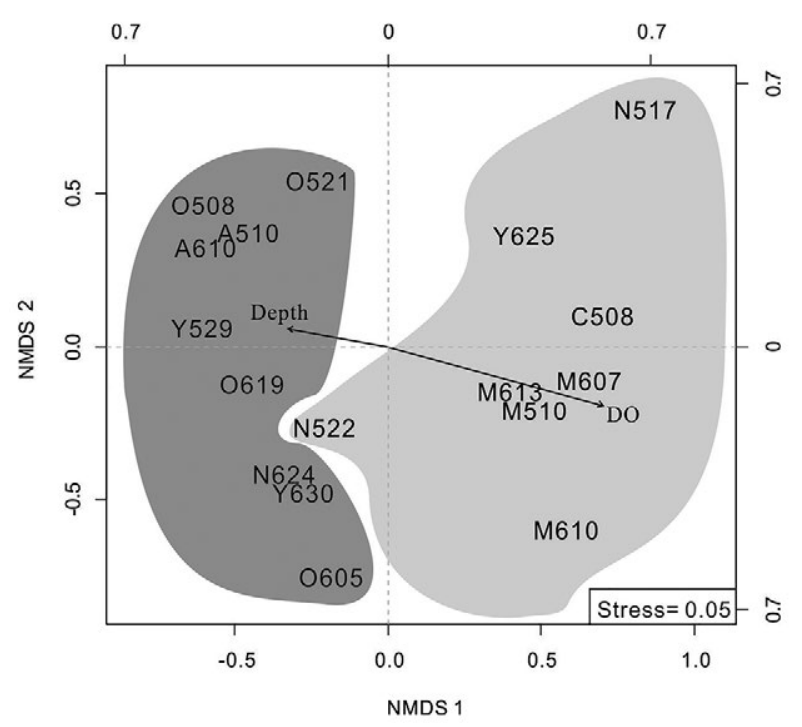

Fig. 5. Non-metric multidimensional scaling (NMDS), illustrating the relationship between distribution of testate amoebae assemblages identified in the Q-R plot (Fig. 4). Assemblage 1 in light gray; Assemblage 2 in dark gray. DO, dissolved oxygen concentration. 


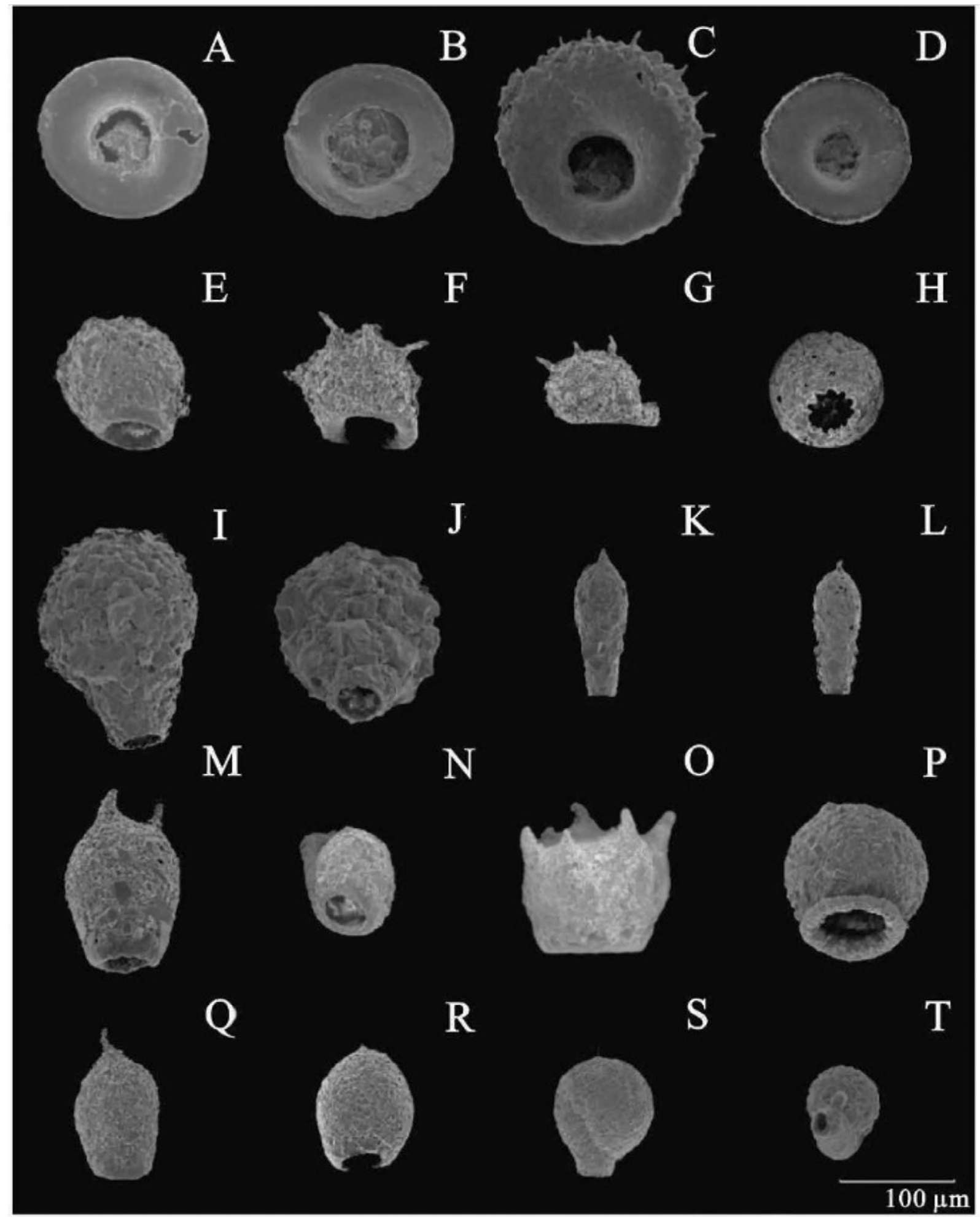

Fig. 6. Testate amoebae from Lacandón Forest lakes (A) ventral view Arcella discoides, (B) ventral view Arcella megastoma, (C) ventral view Centropyxis aculeata strain "aculeata", (D) ventral view Centropyxis aculeata strain "discoides", (E) ventral view Centropyxis constricta strain "aerophila", (F) ventral view Centropyxis constricta strain "constricta", $(\mathrm{G})$ lateral view, (H) ventral view Cucurbitella tricuspis; (I) lateral view Difflugia oblonga strain "oblonga", (J) ventral view, (K) lateral view Difflugia oblonga strain "spinosa", (L) lateral view Difflugia protaeiformis strain "acuminata”, (M) lateral view Difflugia bidens, (N) ventral view Difflugia globula, (O) lateral view Mediolus corona, (P) ventral view Difflugia urceolata strain "urceolata"; (Q) lateral view Difflugia protaeiformis strain "amphoralis", (R) ventral view, (S) lateral view Lesquereusia spiralis, (T) ventral view. 
and $A$. discoides are dominant in low-DO conditions. At oxygen concentration values $<2 \mathrm{mg} \mathrm{L}^{-1}$, SDI of testate amoebae assemblages is low and most species display low relative abundance. Testate amoebae assemblages are also influenced by water depth, which is correlated with dissolved oxygen concentration in these thermally stratified lakes. Our preliminary results indicate that dissolved oxygen concentration and water depth are two important variables that influence the composition of testate rhizopod assemblages in Lacandón Forest lakes, making these protists potentially useful bioindicators for studies of modern and paleoecology.

\section{ACKNOWLEDGMENTS}

We thank the Lacandón community of Nahá, especially Miguel García, for providing facilities and help in the Lacandón Forest, Chiapas. We are grateful to Berenit Mendoza Garfias, Instituto de Biología, UNAM, for providing the electron micrographs. We are also grateful to Mauricio Bonilla, Karla Rubio, Johannes Bücker, Paul Emde, Anais Cisneros, Monserrat Amezcua and Azalea Pérez Hernández for their assistance during the field campaign.

This project was made possible with financial support from the following projects: PAPIIT IA101515, SEPCONACYT 252148, PAPIIT IA100714, CONACYT (190519) and UNAM-DGAPA-PAPIIT (PAPIIT IA100317).

We acknowledge support by the German Research Foundation and the Open Access Publication Funds of the Technische Universität Braunschweig.

\section{REFERENCES}

Alcocer J, Oseguera LA, Sánchez G, González CG, Martínez JR, González R, 2016. Bathymetric and morphometric surveys of the Montebello Lakes, Chiapas. J. Limnol. 75:1343. Doi: /10.4081/jlimnol.2016.1343.

Alves GM, Velho LFM, Simões NR, Lansac-Tôha FA, 2010. Biodiversity of testate amoebae (Arcellinida and Euglyphida) in different habitats of a lake in the Upper Paraná River floodplain. Eur. J. Protistol. 46:310-318.

Anderson MJ, 2017. Permutational Multivariate Analysis of Variance (PERMANOVA). Wiley StatsRef. Doi: 10.1002/9781118445112.stat07841.

Beyens L, Meisterfeld R, 2006. Protozoa: Testate Amoebae, p. 121-153. In: J.P. Smol, H.J. Birks and W.M. Last (eds.), Tracking environmental change using lake sediments: Terrestrial, algal, and siliceous indicators. Springer.

Castillo-Campos G, Narave H, 1992. [Contribución al conocimiento de la vegetación de la Reserva de la Biosfera Montes Azules, Selva Lacandona, Chiapas, México], p. 5185. In: M.A. Vázquez-Sánchez and M.A. Ramos (eds.), [Reserva de la Biosfera Montes Azules: Investigación para su conservación].[Book in Spanish]. Centro de Estudios para la Conservación de los Recursos Naturales, San Cristóbal de Las Casas

Conabio, 2013a. [La biodiversidad en Chiapas: Estudio de Estado,vol. 1].[Book in Spanish]. Comisión Nacional para el Conocimiento y Uso de la Biodiversidad/Gobierno del Estado de Chiapas, México.

Conabio, 2013b. [La biodiversidad en Chiapas: Estudio de Estado, vol. 2].[Book in Spanish]. Comisión Nacional para el Conocimiento y Uso de la Biodiversidad/Gobierno del Estado de Chiapas, México.

Conanp, 2006a. [Programa de conservación y manejo area de proteccion de flora y fauna Naha].[Book in Spanish]. CONANP-SEMARNAT, Mexico D.F.: 180 pp.

Conanp, 2006b. Programa de conservación y manejo área de protección flora y fauna Metzabock. México. CONANPSEMARNAT, Mexico D.F.: 179 pp.

Dalby A, Kumar A, Moore MJ, Patterson R, 2000. Preliminary survey of arcellaceans (thecamoebians) as limnological indicators in tropical Lake Sentani, Irian Jaya, Indonesia. J. Foraminiferal Res. 30:135-142.

Díaz KA, Pérez L, Correa-Metrio A, Franco-Gaviria JF, Echeverría P, Curtis J, Brenner M, 2017. Holocene environmental history of tropical, mid-altitude Lake Ocotalito, México, inferred from ostracodes and nonbiological indicators. Holocene 27:1308-1317.

Ellison RL, Ogden C, 1987. A guide to the study and identification of fossil testate amoebae in quaternary lake sediments. Int. Rev. Hydrobiol. 72:639-652.

Escobar J, Martínez JI, Parra LN, 2005. Thecamoebians (Testaceos Rhizopods) from a tropical Lake: La Fe Reservoir, Antioquia, Colombia. Caldasia 27:293-298.

Han B-P, Wang T, Xu L, Lin QQ, Dumont HJ, 2011. Dynamics in space and time of four testate amoebae (Difflugia spp.) co-existing in the zooplankton of a reservoir in southern China. Eur. J. Protistol. 47:224-230.

ICZN, 1999. International Code of Zoological Nomenclature. The Natural History Museum, London.

Kumar A, Dalby A, 1998. Identification key for Holocene lacustrine arcellacean (Thecamoebian) taxa. Paleontologica Electronica 1:1-39.

Lazcano-Barrero M, Gongora-Arones E, Vogt R, 1992. [Anfibios y reptiles de la Selva Lacandona], p. 145-171. In: M.A. Vásquez Sanchéz and R. M.A. (eds.), [Reserva de la Biósfera Montes Azules, Selva Lacandona: Investigación para su Conservación].[Book in Spanish]. Centro de Estudios para la Conservación de los Recursos Naturales, San Cristóbal de las Casas.

Lee JJ, Leedale G, Bradbury P, 2000. An illustrated guide to the protozoa. Wiley-Blackwell: $1475 \mathrm{pp}$.

Legendre P, Anderson MJ, 1999. Distance-based redundancy analysis: testing multispecies responses in multifactorial ecological experiments. Ecol. Monogr. 69:1-24.

Mcgill BJ, Enquist BJ, Weiher E, Westoby M, 2006. Rebuilding community ecology from functional traits. Trends Ecol. Evol. 21:178-185.

Medioli FS, Scott DB, 1988. Lacustrine thecamoebians (mainly arcellaceans) as potential tools for palaeolimnological interpretations. Palaeogeogr. Palaeocl. 62:361-386.

Neville L, Christie DG, Mccarthy F, Mackinnon M, 2010. 
Biogeographic variation in Thecamoebian (Testate amoeba) assemblages in lakes within various vegetation zones of Alberta, Canada. Int. J. Biodiver. Conserv. 2:215-224.

Ogden CG, Hedley H, 1980. An atlas of freshwater testate amebabe. Oxford University Press, Oxford: 222 pp.

Oksanen J, Kindt R, Legendre P, O'Hara B, Simpson GL, Solymos P, Stevens MHH, Wagner H. 2019. Vegan: Community Ecology Package. R package ver. 2.5-4. Available at: https://cran.r-project.org/web/packages/vegan/ index.html

Padilla RJ, 2007. [Evolución geológica del sureste mexicano desde el Mesozoico al presente en el contexto regional del Golfo de México].[Article in Spanish]. Bol. Soc. Geol. Mex. 59:19-42.

Patterson RT, Burbidge SM, Baker T, 1996. Arcellaceans (thecamoebians) as proxies of arsenic and mercury contamination in northeastern Ontario lakes. J. Foraminiferal Res. 26:172-183.

Patterson RT, Fishbein E, 1989. Re-examination of the statistical methods used to determine the number of point counts needed for micropaleontological quantitative research. J. Paleontol. 63:245-248.

Patterson RT, Kumar A, 2000. Assessment of Arcellacean (Thecamoebian) assemblages, species, and strains as contaminant indicators in James lake, Northeastern, Ontario, Canada. J. Foraminiferal Res. 30:310-320.

Patterson RT, Kumar A, 2002. A review of current testate rhizopod (thecamoebian) research in Canada. Palaeogeogr. Palaeocl. 180:225-251.

Patterson RT, Roe HM, Swindles GT, 2012. Development of an Arcellacea (testate lobose amoebae) based transfer function for sedimentary phosphorus in lakes. Palaeogeogr. Palaeocl. 348-349:32-44.

R Core Team. 2019. R: A language and environment for statistical computing. Foundation for Statistical Computing, Vienna.
Roe HM, Patterson RT, 2014. Arcellacea (Testate Amoebae) as bio-indicators of road salt contamination in lakes. Microb. Ecol. 68:299-313.

Roe HM, Patterson RT, Swindles GT, 2010. Controls on the contemporary distribution of lake thecamoebians (testate amoebae) within the Greater Toronto Area and their potential as water quality indicators. J. Paleolimnol. 43:955-975.

Rzedowski J, 2006. [Vegetación de México].[Book in Spanish]. Comisión Nacional para el Conocimiento y Uso de la Biodiversidad, Mexico City: 405 pp.

Sigala I, Lozano-García S, Escobar J, Pérez L, Gallegos-Neyra E, 2016. Testate amoebae (Amebozoa: Arcellinida) in tropical lakes of Central Mexico. Rev. Biol. Trop. 64:377-397.

Sigala I, Lozano García S, Pérez L, Caballero M, Lugo A, 2018. Ecological drivers of testate amoeba diversity in tropical water bodies of central Mexico. J. Limnol. 77:385-399. doi: 10.4081/jlimnol.2018.1699.

Smol JP, Birks HJB, Last WM, 2001. Tracking environmental change using lake sediments: Volume 4: Zoological indicators. Springer, Dordrecth: 218 pp.

Trench T, 2005. [Representaciones y sus impactos: el caso de los lacandones en la Selva Lacandona].[Article in Spanish]. LiminaR 3:48-69.

Van Hengstum PJ, Reinhardt E, Beddows P, Huang R, Gabriel J, 2008. Thecamoebians (testate amoebae) and foraminifera from three anchialine cenotes in Mexico: Low salinity (1.5$4.5 \mathrm{psu}$ ) faunal transitions. J. Foraminiferal Res. 38:305-317.

Vázquez-Molina Y, Correa-Metrio A, Zawisza E, FrancoGaviria JF, Pérez L, Romero F, Prado B, Charqueño-Célis F, Esperón-Rodríguez M, 2016. Decoupled lake history and regional moisture availability in the middle elevations of tropical Mexico. Rev. Mex. Cienc. Geol. 33:355-364.

Yeates GW, Foissner W, 1995. Testate amoebae as predators of nematodes. Biol. Fert. Soils 20:1-7. 